\title{
Practical theology: A current international perspective
}

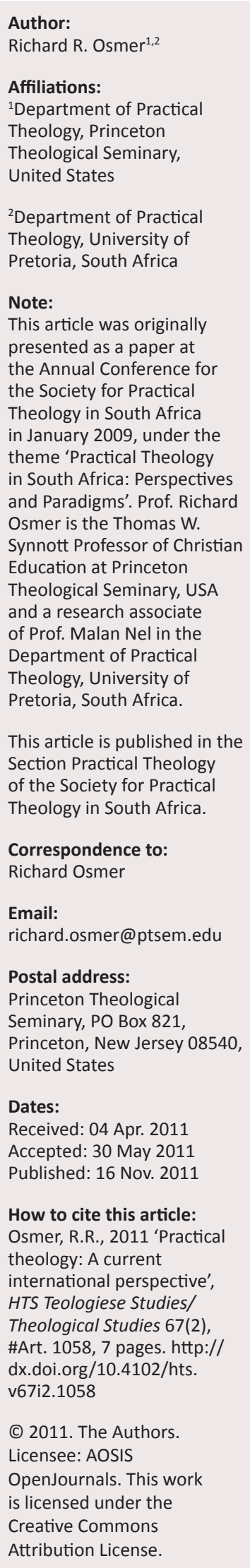

Author

Richard R Osmer ${ }^{1,2}$

Practica

United States

epartment of Practical

Theology, University of

Note: the Annual Conference for

the Society for Practical

Theology in South Africa

in January 2009, under the

theme 'Practical Theology

in South Africa: Perspectives

Osmer is the Thomas W.

Synnott Professor of Christian

Education at Princeton

Teological Seminary, USA

of Prof. Malan $\mathrm{Nel}$ in the

Department of Practical

Theology, University of

This article is published in the Section Practical Theology of the Society for Practical

\section{Correspondence to:}

Email:

richard.osmer@ptsem.edu

Postal address:

Princeton Theological

Seminary, PO Box 821

United States

Dates:

Received: 04 Apr. 201

Accepted: 30 May 2011

Published: 16 Nov. 2011

Theological Studies 67(2),

\#Art. 1058, 7 pages. http://

dx.doi.org/10.4102/hts.

Licensee: AOSIS

OpenJournals. This work

creative Commons

Attribution License.
Drawing on Thomas Kuhn's concept of paradigms, this article explored two levels at which paradigms influence contemporary practical theology. The first level is reflective practice, where pastors and academics carry out the descriptive-empirical, interpretive, normative and pragmatic tasks of practical theological reflection on particular contexts. The second level is metatheoretical, where practical theologians make decisions about how they view the theorypraxis relationship, interdisciplinary work, the relative weight of Scripture, tradition, reason, and experience and the theological rationale that justifies their approach. The article concluded by raising two challenges to the current paradigms of practical theology: the relationship between Christian particularity and the common good, and the wound of reason.

\section{Introduction}

The opening paragraph of Stephen Toulmin's (1972) Human understanding states:

The problem of human understanding is a twofold one. Man [sic] knows, and he is also conscious that he knows. We acquire, possess, and make use of our knowledge; but at the same time, we are aware of our own activities as knowers.

(Toulmin 1972:1)

Toulmin (1972:1) goes on to argue that, historically, human knowledge has developed in 'two complementary ways'. On the one hand, human beings have gathered and made use of knowledge to deal with problems and issues immediately before them. On the other hand, because we 'are aware of our own activities as knowers', human beings have reflected on the frameworks that guide their knowing. This second form of knowledge extends at least as far back as Greek philosophy and, arguably, the Wisdom literature of ancient Israel (Proverbs, Job and Ecclesiastes).

Toulmin offers a helpful starting point for our exploration of the conference theme of perspectives and paradigms in practical theology. This theme focuses our attention on the second form of knowledge identified by Toulmin: reflection on the frameworks that guide knowing. Whilst Toulmin is certainly correct to point out that this sort of reflection has long been a part of human knowledge, it has taken a particular form in science and the academy since the 1960s, especially within the philosophy of science. In the early 1960s, Thomas Kuhn (1962) first popularised the concept of paradigms in The structure of scientific revolutions. He was somewhat ambiguous in his definition of this concept and used it in a variety of ways - from a simple example, to a prototype of good research, to a matrix of assumptions. In this article, I follow Hans Küng in restricting the term to mean an 'interpretative model', which encompasses 'an entire constellation of beliefs, values, techniques, and so on shared by the members of a given community' (Küng 1991:7). What made Kuhn's work so important was the way it effectively broke the hold of modern, especially positivist, understandings of science. Scientific paradigms change, Kuhn argued. They must be understood historically. What counts as good science in one paradigm is viewed as outdated and uninteresting in another.

Today, this insight is taken for granted in many fields. Indeed, it has been developed much further than Kuhn himself. We do not view paradigm change in science and scholarship solely as the movement from one paradigm to another during a period of 'revolutionary' science, in Kuhn's terms. Rather, we think in terms of competing paradigms that are present in the same field at the same time. Here, I believe the manner in which Hans Küng and David Tracy (eds. 1991) follow Kuhn's perspective in Paradigm change in theology is misleading. The task before us is not so much identifying the 'new paradigm' of theology, as Küng and Tracy consistently phrase it, but coming to terms with intellectual pluralism, the reality of multiple and, often, competing paradigms within a single field.

In this article, I will describe the way in which paradigms function at two levels in practical theology today, (1) the level of pastoral and ecclesial practice and (2) the metatheoretical level of 
research and theory-construction in practical theology. I will conclude by identifying the challenges confronting practical theology today, which either must be accommodated by prevailing paradigms or elicit new paradigms.

\section{Paradigms at the level of pastoral and ecclesial practice}

In my recent book, Practical theology: An introduction (Osmer 2008), I argue that much contemporary practical theology attends to four tasks along the lines of a hermeneutical circle or spiral:

- Descriptive-empirical: What is going on? Gathering information to better understand particular episodes, situations, or contexts.

- Interpretive: Why is this going on? Entering into a dialogue with the social sciences to interpret and explain why certain actions and patterns are taking place.

- Normative: What ought to be going on? Raising normative questions from the perspectives of theology, ethics and other fields.

- Pragmatic: How might we respond? Forming an action plan and undertaking specific responses that seek to shape the episode, situation, or context in desirable directions.

I make no claim to originality in my description of these four tasks. Indeed, I believe that something like these four tasks have commonly been represented for many years in the writings of various practical theologians, as well as within the Clinical Pastoral Education (CPE) and Doctor of Ministry programmes and field education seminars. ${ }^{1}$ This leads me to believe that the four tasks I have highlighted are indicative of a particular paradigm in contemporary practical theology what I will call here a paradigm of reflective practice.

The historical roots of this paradigm extend back to the advent of modernity in Europe and the various challenges it posed to traditional, medieval patterns of life, including religion. In the context of modernity, it was not enough for Christian leaders simply to hand on the traditions and practices of the past. Nor was it enough for theologians simply to hand on the Christian cultural heritage of the West along the lines of the liberal arts tradition of the Renaissance and Reformation universities. In both the church and academy, the challenge of developing new forms of Christian practice in a modernising world and providing good reasons to justify these practices was front and centre. It was in this context that practical theology first emerged as an academic discipline in the modern, research university. In the face of modernity, its task was to develop 'theories of practice' and 'rules of art' that might guide the reflective practice of the leaders of the church. ${ }^{2}$

Whilst the historical roots of the reflective practice paradigm lie in the modern period, I believe this interpretive model did

1.For a small sampling of US and UK practical theology in which tasks or dimensions are analogous to those identified in my book see: Browning (ed 1983) Gerkin (1986), Hiltner and Colston (1961), Moore (1971, 1984), Poling and Miller (1985) and Whitehead and Whitehead (1980).

2.These terms come from Friederich Schleiermacher $(1966,1988)$ not fully emerge until the 20th century. The reasons for this are many and only a few can be noted here. In the USA and Europe, the remnants of Western Christendom were still in place through the 19th century but gradually crumbled over the course of the 20th century. Religious, cultural, ethnic and lifestyle pluralism have become more pronounced. Religion also has become 'deinstitutionalised', as denominational identities and structures have become less important. Moreover, the expansion of global telecommunication, migration, law and capitalism have eroded local traditions, evoked fundamentalist reactions and made encounters with cultural 'others' a part of our everyday life. If reflective practice in the context of modernity could still assume a fading Christendom, it can no longer do so today. Church leaders cannot even assume that a programme working well in one congregation will work just as well in a similar congregation in another part of their own country. Indeed, they cannot even assume that a programme that is appealing to middle-aged and older adults will appeal to youth and young adults who belong to the same congregation.

Other social factors might be pointed to, but enough has been said to make my point. If reflective practice was important in the face of the challenges of modernity, it has become doubly so in a post-Christendom, postmodern, globalising world. In this context, the practical theological paradigm of reflective practice has a great deal of plausibility. The church needs leaders who can look closely at their own context and ask what is going on, as well as engage the social sciences to understand why certain events and patterns are occurring. It needs leaders who, firstly, can help a community develop norms and a vision appropriate to its own time and place and, secondly, who have the pragmatic skills to help it better embody these ideals.

I teach the paradigm of reflective practice to my seminary students, often in concert with critical incident reports, case studies, verbatims and qualitative research in congregations. In concluding this section, it is worth noting that this paradigm of practical theology is an alternative to other paradigms that are very much alive in the church today. I am thinking particularly of the paradigms of applied dogmatics found in Protestant orthodoxy and applied Scripture found in contemporary Christian fundamentalism. Both of these paradigms work with similar understandings of applied theology. Application involves the movement from dogmatic or biblical norms to present experience and practice in a oneway fashion. In sharp contrast, the paradigm of reflective practice makes room for reflection on experience and practice and for dialogue with the social sciences as it engages the normative resources of the Christian faith.

\section{Paradigms of practical theology at the metatheoretical level}

The paradigm of reflective practice is situated primarily at the level of pastoral and ecclesial leadership. Paradigms also play a role at a second level of practical theology, that which I call the metatheoretical level of research and theory- 
construction in academic practical theology. ${ }^{3}$ I pointed to this briefly near the end of my introductory book on practical theology, drawing on the concept of a 'reflective equilibrium' (Osmer 2008:241). I learned this concept from the South African philosophical theologian, Wentzel van Huyssteen (1999:277-280), my colleague at Princeton Theological Seminary. A reflective equilibrium assumes that practical theology is, as with other fields today, highly pluralistic. It attempts to take a kind of snapshot of the field in order to identify tasks or elements that are held in common, even as they are carried out in very different ways by different practical theologians.

I believe virtually all practical theologians today give at least some attention to the descriptive-empirical, interpretive, normative, and pragmatic tasks of practical theology - which represent a reflective equilibrium in our field.

Yet how practical theologians conceptualise and carry out these tasks varies widely, determined by decisions at a 'metatheoretical' level. This is indicated in Figure 1 , which is taken from my book, The teaching ministry of congregations (Osmer 2005:306). We can identify at least four metatheoretical issues that practical theologians must deal with either explicitly or implicitly:

- The theory-praxis relationship: Drawing on philosophy, social theory, and/or theology to make decisions about the nature of praxis or practice and theory's relationship to it.

- Sources of justification: The way in which a practical theologian draws on and weights the traditional sources of theological truth - Scripture, tradition, reason and experience.

- Models of cross-disciplinary work: The task of bringing two or more fields into conversation with one another. It includes the selection of dialogue partners and the way in which they are related to theology.

- Theological rationale: An account of the substantive theological convictions that explain why a practical theologian works in certain ways. It often grounds other methodological commitments or guides the way a practical theologian works on a particular issue.

I can illustrate what I have in mind by drawing on a $\mathrm{PhD}$ seminar I taught last semester with my Princeton Theological Seminary colleague in preaching, Sally Brown. We team-taught the departmental seminar which offers an introduction to practical theology to doctoral students in all areas: education and formation, preaching, and pastoral care. Our goal was to introduce students to six strands of contemporary practical theology, giving special attention to those developed in the USA. These six strands and most of the persons and texts applicable to each, as covered in the course, are as follows:

- A postmodern transforming practice approach (Rebecca Chopp, 1987, 'Practical theology and liberation', in L.S.

3.'Meta' means higher or beyond, and what I have in mind by 'metatheoretical' is the matrix of assumptions that a practical theologian carries beyond a single book or theory, and which lies at a higher level.

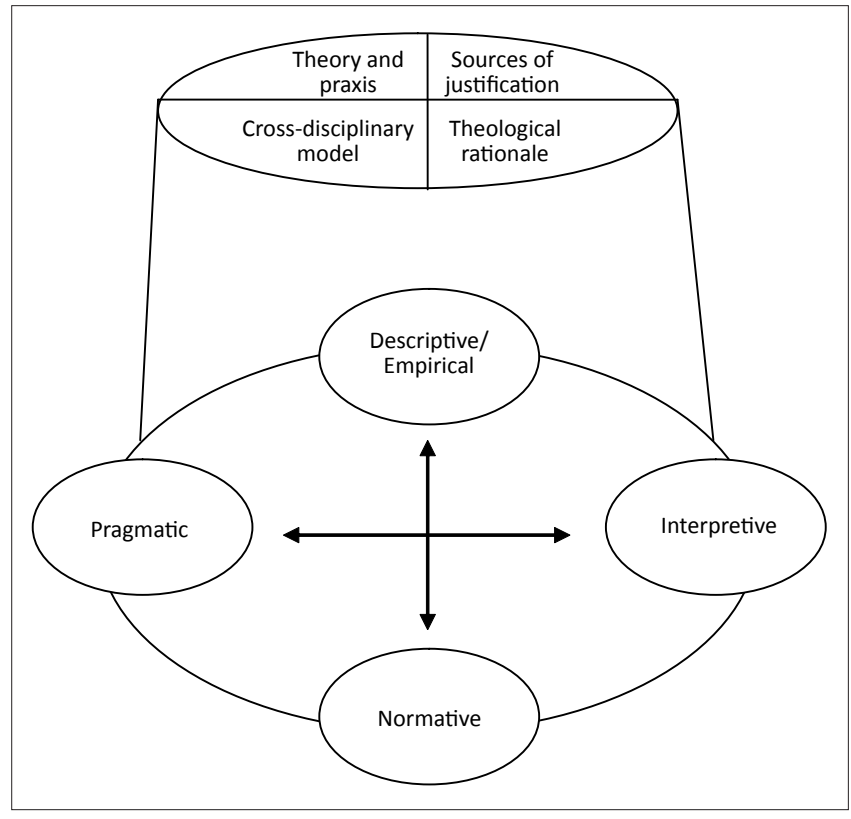

Source: Osmer, R., 2005, The teaching ministry of congregations, Westminster/John Knox Louisville, $\mathrm{KY}$

FIGURE 1: Metatheoretical issues in practical theology.

Mudge and J.N. Poling [eds.], Formation and reflection, Fortress Press, Philadelpia; Mary Fulkerson, 2007, Places of redemption, Oxford University Press, New York; Elaine Graham, 2002, Transforming practice, Wipf and Stock, Eugene).

- An American hermeneutical approach (Don Browning, 1983, Religious ethics and pastoral care, Fortress Press, Philadelphia; James Fowler, 1999, 'The emerging new shape of practical theology', in F. Schweitzer and J. van der Ven [eds.], Practical theology: International perspectives, Peter Lang, New York; Charles Gerkin, 1984, The living human document, Abingdon, Nashville).

- A Dutch South African empirical approach (H.J.C. Pieterse, 2001, Preaching in a context of poverty, Unisa Press, Pretoria).

- A Christo-praxis approach (Ray Anderson, 2001, The shape of practical theology, Inter Varsity Downers Grove).

- An American neo-Aristotelian practices approach (Dorothy Bass and Craig Dykstra [eds.], 2008, For life abundant, Eerdmans, Grand Rapids; Craig Dykstra, 1991, 'Reconceiving practice', in B. Wheeler and E. Farley [eds.], Shifting boundaries, Westminster/John Knox, Louisville).

- An American Barthian approach (Deborah Hunsinger, 1995, Theology \& pastoral counseling, Eerdmans, Grand Rapids; James Loder, 1999, 'Normativity and context in practical theology', in F. Schweitzer and J. van der Ven [eds.], Practical theology: International perspectives, Peter Lang, New York).

My book, Practical theology, was used to orientate students to the field and to introduce the idea of a reflective equilibrium in which members of a field have overlapping tasks and interests but handle them in diverse ways. To gain insight into this diversity in practical theology, we looked at the explicit and implicit decisions various practical theologians make at a metatheoretical level and how these impacted 
their approaches to the descriptive-empirical, interpretive, normative and pragmatic tasks.

By way of illustration, I will now discuss one metatheoretical issue which emerges from each of the strands of practical theology identified above.

\section{The theory-praxis relationship}

According to Elaine Graham (2002), the work of Pierre Bourdieu, Anthony Giddens and postmodern feminist theories of patriarchy are used to describe the ways in which practices of gender are reproduced, resisted, and changed. Practical theological theory involves both learning from and guiding transforming practices of gender in Christian communities.

In Charles Gerkin (1984), the work of Hans-Georg Gadamer and Paul Ricoeur, as well as narrative psychology and object relations theory are used to describe the practice of pastoral counselling as evoking and transforming the identity narratives of counselees. Practical theological theory is portrayed as reflection on the 'living human documents' of pastoral practice.

H.J.C. Pieterse (2001) draws on Jürgen Habermas (as well as Gadamer and Ricoeur) to describe the communicative praxis of the church as it bears testimony to the Gospel in words and deeds in a context of poverty. Here practical theological theory engages in clarifying and guiding the church's praxis of comfort, hope and social transformation.

In Ray Anderson (2001), Dietrich Bonhoeffer's understanding of the interplay of Word and Spirit in congregations serves as the basis of his definition of Christo-praxis, the process by which Christ takes form in new contexts as congregations live as communities-for-others. Here, practical theological theory is viewed as reflection on Christo-praxis in dialogue with Scripture.

In Dorothy Bass and Craig Dykstra (2008), Alaisdair MacIntyre's neo-Aristotelian philosophy of social practices is used to describe the core practices of the Christian community by which God is known and fundamental human needs met. Here, practical theological theory is grounded in and guides the processes of formation taking place through the practices of congregations.

Finally, Deborah Hunsinger (1995) relies on Karl Barth's Christocentric understanding of revelation to describe the priority of theological understanding in the practice of pastoral counselling, without precluding a role for therapeutic psychology. In this perspective, practical theological theory offers reflection on concrete counselling cases and clarification of the appropriate relationship between theology and psychology in pastoral counselling and ministry generally.

It is, of course, impossible to summarise what these practical theologians have to say about the theory-praxis relationship in a few brief sentences. The point I want to underscore is how these different understandings of the theory-praxis relationship impact the way practical theologians handle the descriptive-empirical, interpretive, normative and pragmatic tasks of practical theology. Let me illustrate this in terms of the descriptive-empirical task.

Graham's emphasis on transforming practices of gender leads her to call for a 'critical phenomenology' to study communities in which such practices are found. This is designed to assist these communities in gleaning the wisdom of their struggle against patriarchy and to help them learn from other communities who are also engaged in this struggle. In Graham's view, this sort of empirical investigation of communities of transforming practice potentially has ramifications for the normative task of practical theology, because transforming practice is generative of new theological understandings. This understanding of the descriptive-empirical task stands in sharp contrast to Hunsinger's Christocentric Barthianism, which views clinical data and cases as providing insight into the dynamics of particular relationships, but offers nothing to the theologically defined purposes and norms of pastoral counselling. Dykstra's focus on ecclesial practices centres the descriptive-empirical task primarily on the internal life of congregations. In contrast, Pieterse quite explicitly makes the subject of empirical investigation the congregation-incontext, drawing on a wide range of research to portray the context of poverty in which South African congregations communicate the Gospel.

Again, the point that I want to make here is that whilst it may be true that empirical research, social scientific interpretation, normative assessment and pragmatic intervention are found across practical theology today, the ways in which these tasks are conceptualised and carried out vary widely because of decisions made at a metatheoretical level. Typically, decisions in one of the metatheoretical areas I have described are intertwined with decisions made in others areas. For example, Graham's understanding of transforming practice is closely related to her theological rationale in which God is portrayed as liberating. It also is related to the weight she gives to women's experience in her implicit evaluation of the traditional sources of theological justification and her use of a revised praxis model of interdisciplinary work. Decisions at a metatheoretical level hang together and represent a kind of paradigm, or interpretive model, in Kuhn's sense.

\section{Two challenges before contemporary practical theology: A perspective}

I began this article with Toulmin's insight that human beings not only acquire, possess and make use of knowledge, but are also aware of their own activities as knowers. In the two previous sections, I have attempted to deepen our understanding of our 'activities as knowers' by identifying paradigms that operate at two levels of practical theological reflection. In this final section, I identify two challenges facing contemporary practical theology. As Kuhn pointed 
out, at any given time, paradigms face anomalies, intellectual puzzles or data sets that they cannot really explain. Most of the time, these anomalies are simply put to one side as problems that will be handled at a later time. But when they become important to a field, the prevailing paradigms must find ways of accommodating them or else give way to new paradigms. Perhaps, the two challenges I identify fit this pattern.

\section{Challenge 1: Christian particularity and the common good}

The first challenge may be stated as follows: 'Practical theology faces the challenge of grounding its identity and purpose in the mission of the church without sacrificing a commitment to scholarship and research that contributes, not only to the church, but also, to the common good.' This challenge to practical theology takes different forms in different parts of the world. In the USA, South Africa and other places where congregations retain vitality, there is a great deal of pressure on practical theologians to focus on teaching future ministers the skills they will need to lead the church. There is little recognition by administrators and faculty colleagues that practical theologians are constructive theologians and researchers, not just wise practitioners of Christian leadership. In much of Europe, the opposite is the case. Practical theology struggles to hold on to its place in secular universities that are situated in cultural contexts in which congregational vitality is minimal. The temptation is to allow religious or cultural studies to define the field, minimising the way practical theology is grounded in the identity of a particular religious community. From my perspective, the core challenge facing practical theologians in all of these contexts is to ground practical theology as a critical, reflective enterprise in the distinctive identity of the Christian community, without eliminating its scholarly contribution and relevance to the common good. Let me share my thoughts on one way of responding to this challenge.

We can begin, I believe, by recognising that the end of modernity has removed a formidable obstacle in our path. The modernist portrait of science offering public, objective and verifiable knowledge, whilst theology offers private, subjective and dogmatic knowledge is largely discredited. It has given way to an understanding that various spheres, fields, or domains of life have their own distinctive traditions and patterns of rationality and that natural science does not serve as the paradigm of rationality for every area of life. As a rational enterprise of the Christian community, theology has both the right and obligation to discern its own unique forms of critical reflection. In the postfoundationalist perspective to which I subscribe, this is accompanied by an affirmation of the common resources of rationality that are shared across various rational enterprises, making rational dialogue possible across cultures, disciplines and paradigms within the same field (Van Huyssteen 1999:111-286). It is not necessary for practical theology to leave behind its own particularity to participate in the larger human conversation about the common good, a conversation to which many fields contribute.
Claiming our Christian particularity immediately confronts us with the task of describing on theological grounds practical theology's commitment to both the church and the world. This is important, for more than a few theological perspectives have emerged in the wake of modernity which define theology primarily as an conversation internal to the Christian community and its contribution to public life as little more than a witness to the evangel in the form of proclamation or evangelism. This perspective is found, not only amongst conservative Protestant theologians, but also in the Yale School theology of George Lindbeck and Hans Frei and the character ethics of Stanley Hauerwas. I believe an alternative can be developed out of the theological trajectory of the missio Dei, emerging initially in the international ecumenical and missionary organisations of the past century and, then, developing in diverse ways in the writings of David Bosch (1991), Jürgen Moltmann (1977) and Leslie Newbigin (1989), amongst many others.

In the missio Dei, the mission of the church is located within the mission of God, which is universal in scope. Concern for the church's mission is not a retreat into the private world of religion but a matter of discerning the church's participation in God's creating, guiding and redeeming purposes for the world. David Bosch (1991) offers a helpful image of a missional ecclesiology in which the church is viewed as an ellipse with two foci:

In and around the first it acknowledges and enjoys the source of its life; this is where worship and prayer are emphasized. From and through the second focus, the church engages and challenges the world. This is a forth-going and self-spending focus, where service, mission and evangelism are stressed. Neither focus should ever be at the expense of the other; rather, they stand in each other's service. The church's identity sustains its relevance and involvement.

(Bosch 1991:385)

Bosch's image of a missional church provides a helpful way of thinking about the scholarship and research of practical theology. In serving the mission of the church, it attends to both identity and relevance. It contributes to the upbuilding of the church and to the church's contribution to the common good. To this, Jürgen Moltmann adds a very important point. The church's mission is not merely quantitative, that is, concerned only with increasing membership, but also, qualitative, 'aimed at creating a climate for life in fellowship' through dialogue, friendship, and suffering in solidarity with our 'partners in history' (Moltmann 1977:152, 159-64). This includes listening and learning, as well as speaking and sharing. It is the broader context in which practical theology makes its own distinctive contribution to the common good.

\section{Challenge 2: The wound of reason}

A second challenge facing practical theology is that which I call the 'wound of reason'. By this I mean the massive damage and danger modern science and technology have unleashed upon the world. Both nature and human communities have been wounded and it is quite conceivable that the worst is yet to come. With this image, I also want to communicate 
that reason itself has been wounded by its complicity in this evil. The pretensions of 'autonomous man' under the guise of objectivity and progress may be interpreted theologically as an overreaching of a human reason that is held by captive by greed and the lust for power. A plausible argument can be made that nature and human communities would have been much better off if science and technology had not entered into an unholy communion with industrialisation about 150 years ago. The world would have been better off it had developed more slowly in the context of rural and small town societies. This would have allowed communities to form cultural values and institutions with which to guide and limit science's achievements and to channel them in directions other than the endless trivial novelties of consumerism and military weaponry. Whilst 'autonomous man' may have fallen, the wounds inflicted have given rise to a great deal of scepticism about reason, even as they have left us all staring into the abyss.

The wound of reason poses a number of questions to practical theology, and I will end this article by raising these questions and pointing to only the briefest of answers. For example, too often in the past and present, practical theology has coped with its perennial insecurity by adopting the mantle of legitimacy offered by other fields, especially the social sciences. What would an explicitly Christian form of practical theological reasoning really look like and how might it claim its Christian grounding whilst remaining open to dialogue with other fields and religions?

In the face of the wounds inflicted by 'autonomous man', to what extent must practical theology become an explicitly political theology? What would this look like now that the pretensions of modernist social theories have been exposed, including Marxist-Hegelian theories so important to the political theologies of Western Europe, Latin American liberation theology and early American feminism? Does poststructuralist political theory really offer a viable alternative? How do we acknowledge the pluralism of postmodern understandings of cultures and reason without cutting the nerve of a commitment to social transformation?

Finally, how might practical theology exert greater influence on the other theological disciplines, especially dogmatic theology, which too often builds dogmatic fortresses constructed and defended in a quest for inner, rational coherence? Toulmin (1972) makes this point in a particularly good way:

That, in science and philosophy alike, an exclusive preoccupation with logical systematicity has been destructive of both historical understanding and rational criticism. Men [sic] demonstrate their rationality, not by ordering their concepts and beliefs in tidy formal structures, but by their preparedness to respond to novel situations with open minds-acknowledging the shortcomings of their former procedures and moving beyond them. Here again, the key notions are 'adaptation' and 'demand', rather than 'form' and 'validity'. The philosophical agenda proposed here sets aside all such assumptions in favor of patterns of analysis which are at once more historical, more empirical and more pragmatic.

(Toulmin 1972:vii-viii)
There are no simple answers to these questions, but several lines of thinking seem especially promising. Firstly, after the 'turns' toward hermeneutics and practice in philosophy and science, it is increasingly evident that all forms of inquiry, including those of science, must acknowledge their grounding in interpretive traditions. Increasingly, this has led to an acknowledgement of the role of values and ethics in inquiry - at the personal, disciplinary and corporate levels. This is a conversation to which religious communities have both the right and obligation to contribute, as the boundaries and foundations of life itself are pressed toward the edge.

Secondly, it is apparent that political theory can no longer be conducted in the framework of modernity, focusing on the nation-state, national civil societies and so forth, or assuming the 'objectivity' of modernist epistemologies. In an era of globalisation, it is apparent that global economic institutions have far outstripped the institutions of governance and law and that the encounter of civilisations and cultural traditions have relativised the pretensions of the modern West. The pressing task today is to imagine and theorise alternatives to a global order totally dominated by the logic and practice of the global marketplace. At present, only hints of such alternatives have begun to emerge. Unless practical theology attends to these alternatives and makes its own contribution to their emergence, it is likely to be left behind as an irrelevant vestige of modern academic life.

Thirdly, it is possible that practical theology will emerge as the premier discipline in theology if - and this is a big if it finds ways of linking its strong commitment to particular contexts and practice to a larger vision of the whole, especially a freshly imagined global whole that might emerge. Here, it must capitalise on its commitment to the dialectic of theory and practice beyond 'logical systematicity', as Toulmin puts it above. Thus, its ascendance in theology is highly dependent on its ability to participate in the broader recovery of practical reason across philosophy and science today. A recovery of the political in practical theology therefore must be a part of the broader recovery of practical reason or, more particularly, practical theological reason. This can be identified as a recovery, or, perhaps better, as a constructive contribution that practical theology is well-situated to make, if it transcends its current disciplinary paradigms and, in the process, transforms, not only itself, but the field of theology as a whole.

\section{Acknowledgements Competing interests}

The author declares that he has no financial or personal relationship(s) which may have inappropriately influenced him in writing this article.

\section{References}

Bosch, D., 1991, Transforming mission: Paradigm shifts in theology of mission, Orbis, Maryknoll, NY.

Browning, D. (ed.), 1983, Practical theology: The emerging field in theology, church and world, Harper \& Row, San Francisco, CA 
Gerkin, C., 1986, Widening the horizons: Pastoral responses to a fragmented society, Westminster Press, Philadelphia, PA.

Hiltner, S. \& Colston, L., 1961, The context of pastoral counseling, Abingdon, New York, NY.

Kuhn, T., 1962, The structure of scientific revolutions, 2nd edn., Chicago University Press, Chicago, IL.

Küng, H., 1991, 'Paradigm change in theology: A proposal for discussion', in H. Küng \& D. Tracy (eds.), Paradigm change in theology: A symposium for the future, p. 7, Crossroad, New York, NY.

Küng, H. \& Tracy, D. (eds.), 1991, Paradigm change in theology: A symposium for the future, Crossroad, New York, NY.

Moltmann, J., 1977, The church in the power of the spirit: A contribution to messianic ecclesiology, Harper \& Row, San Francisco, CA.

Moore, A., 1971, 'The place of scientific models and theological reflection in the practice of ministry', Pastoral Psychology 22(210), 25-34.

Moore, A., 1984, 'A recovery of theological nerve', Religious Education, 79(1, Winter), $24-28$
Newbigen, L., 1989, The gospel in a pluralist society, Eerdmans, Grand Rapids, MI. Osmer, R., 2005, The teaching ministry of congregations, Westminster/John Knox, Louisville, KY.

Osmer, R., 2008, Practical theology: An introduction, Eerdmans, Grand Rapids, MI.

Poling, J. \& Miller, D., 1985, Foundations for a practical theology of ministry, Abingdon, Nashville, TN.

Schleiermacher, F., 1966, Brief outline on the study of theology, transl. T. Tice, John Knox Press, Richmond, VA.

Schleiermacher, F., 1988, Christian caring: Selections from Practical Theology, ed. J. Duke \& H. Stone, Fortress, Philadelphia, PA.

Toulmin, S., 1972, Human understanding, vol. 1, Princeton University Press, Princeton,

Van Huyssteen, J.W., 1999, The shaping of rationality: Toward interdisciplinarity in theology and science, Eerdmans, Grand Rapids, MI.

Whitehead, J. \& Whitehead, E., 1980, Method in ministry: Theological reflection and Christian ministry, Seabury Press, New York, NY. 